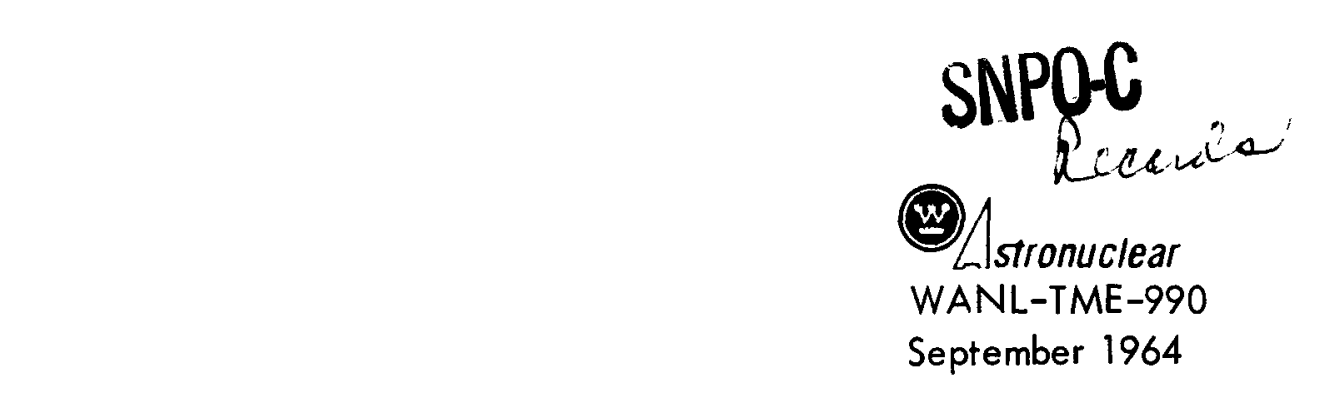

\title{
CONTROL DRUM FRICTION TEST
}

(EML-49)

\author{
Westinghouse Electric Corporation \\ Astronuclear Laboratory \\ P. O. Box 10864 \\ Pittsburgh, Pennsylvania 15236
}
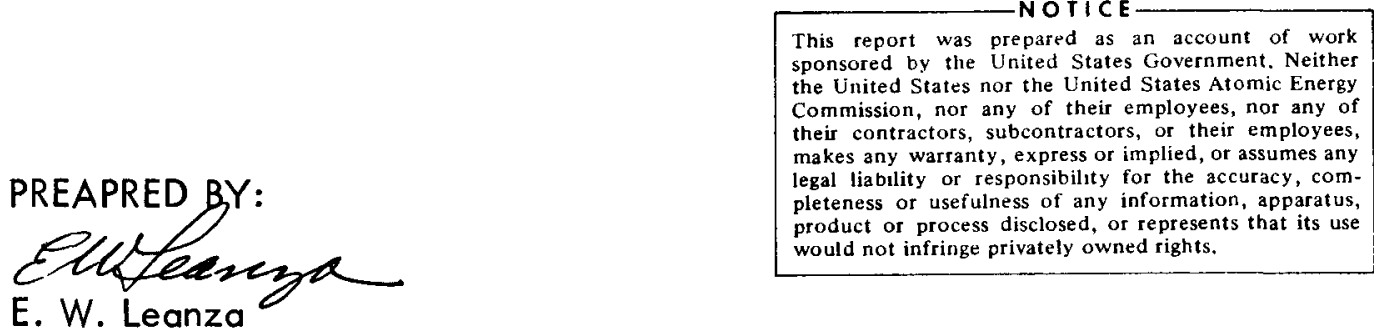

E. W. Leanza

Support Structure \& Cryogenic Experiments

\section{APPROVED BY:}

m. I Bufano

N. S. Bifand Supervisor

Support Structure \& Cryogenic Experiments

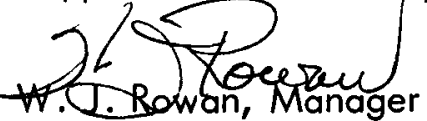

Engineering Mechanics

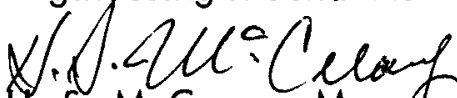

H. S. McCreary, Mangger

Experimental Engineeting

NIM. $?$

W. G. Roman, Manager

Reactor Engineering, NERVA Project
INFORMATION CATEGORY

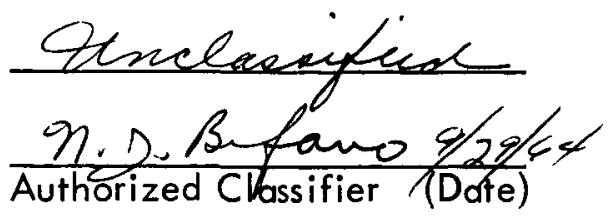

/fep 


\section{DISCLAIMER}

This report was prepared as an account of work sponsored by an agency of the United States Government. Neither the United States Government nor any agency Thereof, nor any of their employees, makes any warranty, express or implied, or assumes any legal liability or responsibility for the accuracy, completeness, or usefulness of any information, apparatus, product, or process disclosed, or represents that its use would not infringe privately owned rights. Reference herein to any specific commercial product, process, or service by trade name, trademark, manufacturer, or otherwise does not necessarily constitute or imply its endorsement, recommendation, or favoring by the United States Government or any agency thereof. The views and opinions of authors expressed herein do not necessarily state or reflect those of the United States Government or any agency thereof. 


\section{DISCLAIMER}

Portions of this document may be illegible in electronic image products. Images are produced from the best available original document. 


\section{TABLE OF CONTENTS}

Page

1.0 Summary

2.0 Introduction

$3.0 \quad$ Test Description 1

$\begin{array}{lll}4.0 & \text { Test Results } & 2\end{array}$

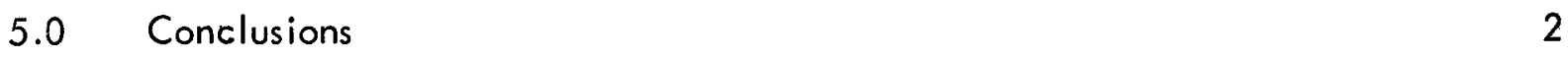

$\begin{array}{ll}\text { Figure } & 3\end{array}$

$\begin{array}{ll}\text { Table } & 4\end{array}$ 


\subsection{SUMMARY}

A friction test was performed to determine the torque required to rotate a control drum under various conditions of control drum and outer reflector sector interference. The control drum was bowed to obtain effective drum-sector interfcrences of 0.003 to $0.015 \mathrm{in}$. For the range of interferences tested, torques of about 200 to 1200 in.-lb were measured, however the coefficient of friction developed was almost constant and varied from 0.32 to 0.40 .

\subsection{INTRODUCTION}

During the NRX-Al high flow ramp tests, control drum actuator stall was experienced. This difficulty was felt to be due to control drum and reflector sector bow resulting from transient thermal gradients in the drum and sector. In order to correlate drum-sector bow with drum turning torque, it was decided to perform friction tests in which a mechanically bowed drum would be rotated in a simulated reflector sector.

\subsection{TEST DESCRIPTION}

The control drum was installed in a test fixture where it was supported from its ball bearings. and various bows could be obtained by turning a turnbuckle which was connected to clamps at each end of the drum. The fixture was then mounted in a tensile testing machine and a beryllium bar, machined to simulate the bore of a reflector sector, was attached to the movable crosshead of the tensile testing machine and held in contact with the control drum as shown in Figure 1.

A load deflection curve of the control drum was obtained with the turnbuckle disconnected from the drum end clamps to determine the spring rate of the drum under 
the normal drum-sector contact loading which was believed to have occurred during the Al cold flow tests. Then the turnbuckle was adjusted to produce various effective drum-sector interference conditions and the corresponding drum normal forces. The torque required to rotate the control drum was measured with a torque wrench attached to the dome end control drum bearing shaft.

\subsection{TEST RESULTS}

The normal forces and torques measured during the test and the coefficients of friction calculated therefrom are listed in Table I.

\subsection{CONCLUSIONS}

Since the NRX-Al control drum actuator maximum torque output was $1200 \mathrm{in.}-\mathrm{lb}$, the results of this test indicate that drum-sector interferences of about $0.015 \mathrm{in.}$ or higher were required to produce actuator stall during the cold flow tests. 


\section{(w) Lstronuclear}

WANL-TME-990

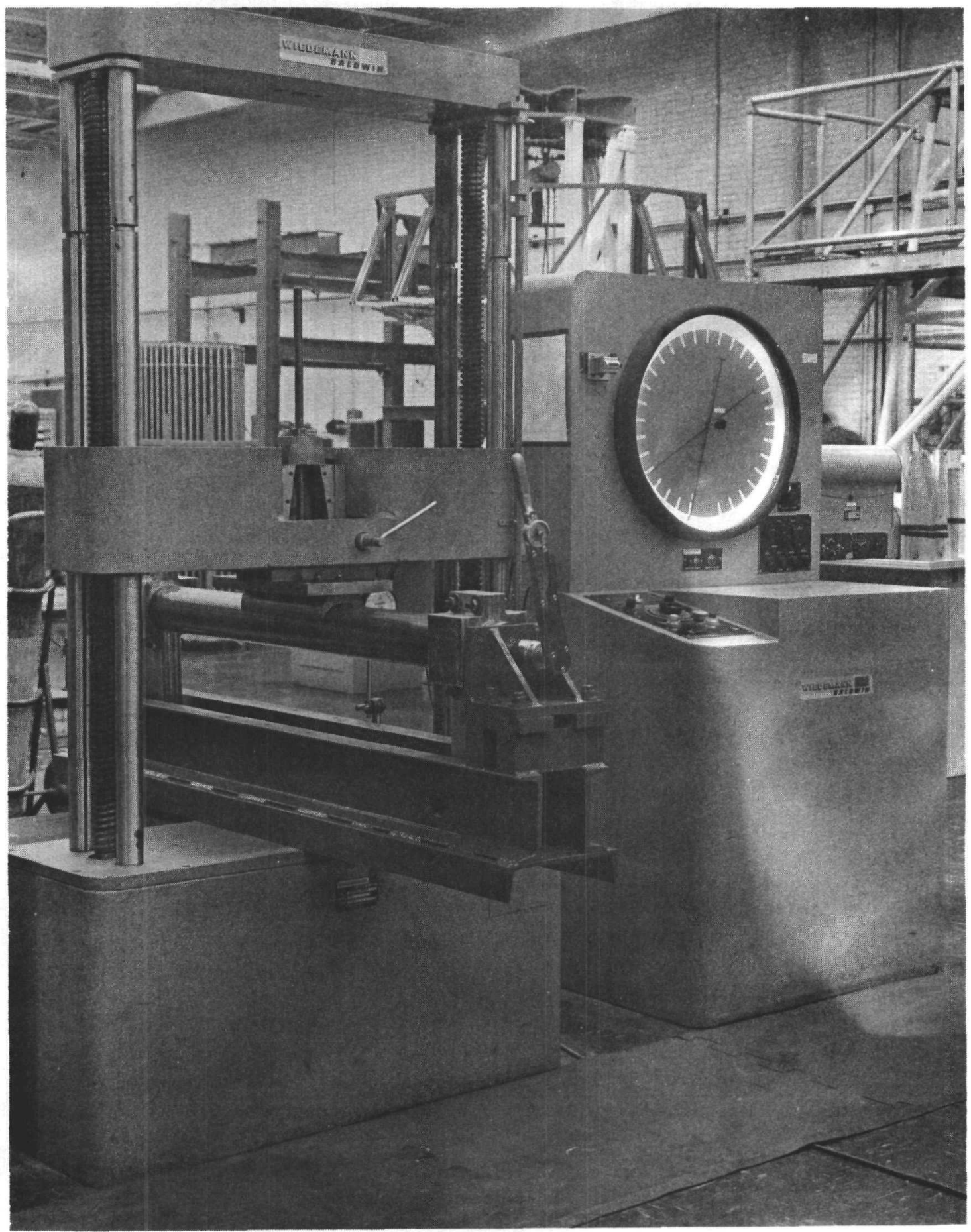

FIGURE 1

CONTROL DRUM FRICTION TEST RIG MOUNTED ON TENSILE MACHINE 


\section{(4) Istronuclear \\ WANL-TME-990}

TABLE I

\begin{tabular}{l}
$\begin{array}{c}\text { Drum-Sector } \\
\text { Interference } \\
\text { (in.) }\end{array}$ \\
\hline 0.003 \\
0.006 \\
0.009 \\
0.012 \\
0.015
\end{tabular}

\begin{tabular}{cc}
$\begin{array}{c}\text { Friction } \\
\text { Torque } \\
\text { (in.-lb) }\end{array}$ & $\begin{array}{c}\text { Coefficient of } \\
\text { Friction }\end{array}$ \\
\hline 198 & 0.34 \\
380 & 0.32 \\
768 & 0.40 \\
1020 & 0.41 \\
1200 & 0.40
\end{tabular}

